\title{
Values within the Context of Postmodernity and Their Roles in Happiness: A Research on University Students
}

\author{
Yemliha Coşkun
}

Department of Educational Sciences, Kahramanmaras Sutcu Imam University, Kahramanmaras, Turkey

Copyright $(02017$ by authors, all rights reserved. Authors agree that this article remains permanently open access under the terms of the Creative Commons Attribution License 4.0 International License

\begin{abstract}
The aim of the study is to explore the relation between values and happiness of the university students in the Context of Postmodernity. The research is a descriptive study in the screening model. The study was carried out with 376 students from the faculties of Physical Education and Sports, Education, Science and Letters, Business, Theology, Engineering, Forestry and Agriculture at Kahramanmaras Sutcu Imam University during the spring semester of 2016-2017 academic year. They were selected by convenience sampling method. 'Personal Information Form' and 'Values Scale', the original of which was created by Calp developed by the researcher and the 'Oxford Happiness Scale' developed by Dogan and Sapmaz were used as data collection tools. The research data were analyzed the descriptive and correlational statistics technique in terms of SPSS. The university students' values were found to be very high while their happiness levels were above the average; a positive and medium level relationship was identified between participants' values and happiness levels. Female students were found to have higher levels of values and happiness than male students. Students studying in the faculty of theology were determined to have the highest level of value and happiness.
\end{abstract}

Keywords Postmodernity, Values, Happiness, University Students

\section{Introduction}

Modernity is regarded as the expression of a new order grounded on rationality and secularity, which can clearly articulate the relation between human actions and world order. The new order promises to offer a whole new, easy, orderly and therefore happy life to man by foreshadowing to rationalize science, reason, and progress of the world as well as society as a part of the universe through a completely emancipated mind. Thence, each field that concerns human life in the modernization process is at the target of change. Modern man, who assumes that he can rise to a challenge on the basis of unlimited trust with the enlightened reason, endeavors to build new social, economic and even moral systems for him depending on the requirements of the modern age $[1,2]$.

Modernity holding an innovative, progressive, rational and universal qualification is dominated by a proposition that is being independent of the past and the traditional in line with finding the present much more progressive than the past. This characteristic of modernity is discussed by the innovative-traditionalist or progressive-regressive duality, still the most criticized part of it is to be rational and universal. If a primal moment for this quality is sought, it is fundamental to recede to the seventeenth century when Rene Descartes (1596-1650) proclaimed the rational theory [3]. Modernity refers to the great and profound changes that Europe has experienced since the 17th century in the sense of the economic, social, cultural and political contexts. The transition to modernity has emerged with four fundamental revolutions: the scientific revolution initiated by Newton, the political revolution based on the legitimacy of power, the cultural revolution and the industrial revolution, which emphasize the supremacy of reason.

The wisdom and scientific knowledge of the enlightenment movement that emerged with Renaissance and Reform movements and that constitute the foundational infrastructure of modernity have put a firm step on almost the whole process [4]. Modernity is regarded as the process by which objective science, universal law and moral are developed, and man with full of freedom reestablishes his own and social life under the strength of mind and science [4]. In this process led by the mind, the 20th century was considered as a great advance. This progress in scientific and technological progress has led to numerous changes in every aspect of life. However, it is unlikely to state that social, political and cultural developments pave the way for these advances in science and technology. Big changes in science and technology have led to great problems in human and social life.

For centuries, people have been forced to adapt to the 
changing world of values and faced with various problems in the presence of new developments, yet they have felt inadequate in producing solutions [5] as traditional societies are in a process of a great change from simple structures to complex one in modernization that brings about differentiation in the structure of society. Traditional societies possess homogeneous values, though subcultures and countercultures are few. However, modern societies have a secular character. The existence of many subcultures and counter cultures are essential features of modern societies. In traditional societies, tolerance to diversity does not almost exist. Diversity is one of the significant factors in the modernization of societies. In other respects, social control is followed through formal laws in modern societies.

The government intervenes society, while it is not dominant in traditional societies [6]. The regulation of economic and commercial relations with legal rules, the establishment of public administration and legal state, opposing traditions and privileges are among the purposes of the societies developed by modern ideas and practices. In such case, "mind" becomes the central role-playing factor. Weber's concepts such as secularization, rationalization and legal rational authority unerringly define modernity, and modernity process leads to the emergence of formal rules of law in the sphere of social norms with reference to organizing human relations and shaping human behaviors. Within the historical process, developing social norms are neutralized, and law rules consciously designed and enforced by a certain legislative authority become effective without the direct conscious human intervention. On the other hand, individualism is considered by many as the greatest achievement of modern civilization, and individuals on this point begin to use their right to choose and determine their own lifestyles. Yet, the fact that individualism develops in the direction of atomism and tends to become introverted reduces the sensitivity to the social. As people concentrate on their individual habits, they just focus on their self. Such a development undoubtedly makes people indifferent to others and society. Values such as productivity, achievement, consumption and technology are emphasized through instrumental mind; whereas those like human and moral dimension, social sensitivity and respect to the environment weaken. During the process of modernization, the weakening of face-to-face relationships and interactions, the increasing possibility of direct interaction opportunities make the formation of moral values and norms almost impossible despite the removal of temporal and spatial distances [7]. This leaves people of the modern society alone and also alone in the frustration of everyday life as an individual whose ties are disconnected from their past and who are free from values (or equipped with instrumental intellectual values) [8].

When we come closer to the point of view on the subject, the concept of traditional morality has undergone a remarkable transformation in the modern plane: value corruption that arises in family relations and other social institutions in the course of time, pushing the division of labor and consciousness of duty that is necessary for living together to the second plan, whipping the feeling of independence and individualization "as a vision of life [9]. Modernity has created the perception that my priority is more important than law and society because we cannot define the conditions that conscience protects, that is, moral responsibility, which we can describe as conscientious law. The inability to develop necessary moral values has resulted in a more selfish, crueler, more irresponsible development of the second and third generations. Even though people are more affluent in the modern world, this is not enough to make them happy. However, it may be considered as a good way for a modern man who longs for being free to generate reliable ideas, being happy and retaining the abandoned values while protecting the positive gains of modernization [10]. Values play significant role in the formation of personality and healthy society. The moral and cultural values which are regarded as the backbone of a civilized society, which is largely eroded by the modern world [11], and which are transferred from the beginning to the end in order to keep the communities alive [12], to protect and preserve the unity and solidarity are reflected outward in schemas with common patterns of behavior within society. The behavioral patterns with these common values that are internalized and adopted by individuals due to the pressure and influence of social principles and rules keep the balance of society and order along with making social life possible $[13,14]$. While the undeniable and necessity of values reveal its importance, the contemplation of modernity regarding the development of values on the basis of scientificness leads to inadequacy in the development of values as science cannot produce values on its own; further it cannot present the best kind of society in which human values develop[15].

The concept of value which constitutes one of the main problematic areas of social sciences and which has been dealt with various branches of science [16]is literally expressed as truths, mistakes and flawless situation that are determined by beliefs and intuitions, irrespective of the individual's own interests [17]. In different definitions, it refers to one's beliefs and ideals through which the basis for all decisions, interests, goals and behaviors that guide the actions of one's own is formed [18]. In another definition; it is considered as measures that direct our behaviors, the desired thing, humans' attitudes towards events, and ideal forms of behavior or life goals [19]. Besides, it is defined as socially acceptable norms for evaluating a person, an object, or any situation [11]. Just as we consider what we have or the quality as value; we define our goals as values which are the desires of ourselves, which guide people's lives and which are of importance to us, and that such values can emerge with 
action but not with a physical presence [19]. In other words, values are the determination of principles or standards of behavior. Values organize and guide human behaviors and actions in daily life. They are reserved in each word we choose and speak, in what we wear, in our interaction, in our perceptions, and in the reactions of others to what we say [11]. The development of values takes place during the socialization process [11]. Each social order is a system of values. All values from technical to ethical and religious constitute the social system. Among these values, there is a terminal-instrumental dual. Terminal values are below and the instrumental values are above. The summation of terminal values is called absolute value in classical theory. Thus, we can talk about various terminal or absolute values in the social value systems [20], and these values show the ultimate goal and the result is what is expected. Instrumental values are those that are expected to guide individuals in order to achieve terminal values [21]. Furthermore, values can be divided into three categories in terms of their essence. The first is the immanent values that refer to consciousness, that is technical, art and knowledge values. The second is the values of transcendence. Transcendent values are moral and religious. In these, sensory data and consciousness only serve as means. Yet, this may be more or less an insignificant degree. The third is normative values which are not really values, but measures of all values and examples of change. The task of these values is to compare and measure other values [20].

Having evaluated values in general terms, it seems they are not fixed, invariant rules. Just as societies are changing and reshaping, some values are also influenced and changed by events in society, a new form is formed, and new values are formed [22]. Hence, it is likely that various factors such as environment, change, communication and technological developments play significant roles in the change of some values [23]. Value, a concept that sometimes changes depending upon time and place, shines for providing individuals with acquiring values so as to give up their selfish aims especially in today's world and using them in their lives [24]. Ideally, values expressed as normative judgments, which are adopted by all members of society, are the basic norms [25]. There are social relations and interactions on the basis of moral values and norms. Mutual contact, communication and interaction are of paramount importance both for the individuals, groups and communities they belong to. Without them, none of them can survive. Values emerge as criteria in people's thoughts, attitudes and behaviors and constitute an indispensable element of social life. All in a society or group's life is perceived and absorbed by means of values. People adopt the values of the communities or groups they live in and use them as criteria in their thinking, attitudes and behaviors. Thus, they have access to general judgments such as better, more accurate, more appropriate, better, more important and fairer [7]. This brings society together in harmony with itself and serves as a mechanism that protects and controls society against confusion and conflict [26]; on the contrary, providing that the values are weakened or become inadequate, it may cause problems that threaten the social self such as cultural dissolution and social separation, particularly in societies [27], thus affecting the psychological well-being of the individuals, that is, their happiness, negatively. In short, the notion of value, which is embedded in aesthetics, economics and philosophy and which has a wide usage, is also significant in understanding, grasping and explaining the structure of human being and spiritual world because the success of people, their actions, and the integrity of their lives in general, are confined and directed with certain values. As long as a person is alive, he must always take a certain stance, that is, each attitude is based on a value or a sense of value. In brief, all kinds of goals, ideals and values, relations and interests, passions and desires, power, love and hate, belief and denials, loyalty and righteousness are all values and based on a value [28]. However, people of modern society are alone and alone in the throbbing of everyday life as an individual whose ties are disconnected from their past, free from values (or equipped with instrumental intellectual values) [8]. Individual who are trying to establish their lives in such a world attribute positive meaning towards what they see correct while negative if they do not consider it appropriate. This leads to disarray, disruption of feelings and thoughts, confusion in common values, beliefs and concepts, and even conflicts. Still, people coexist with others. He evolves with them, expose to several changes, and gains value. Thereby, developing psychological well-being, that is to develop human relations on the basis of common values, is remarkable in ensuring happiness. Otherwise, man who is disinterested towards others fluctuates due to frictions and conflicts that are the source of anxiety and anger [29]. However, positive interpersonal relationships, that are well-being, have an effect upon being happy.

Related literature reveals various factors that affect happiness and the nature of happiness. One of them is the value orientations. The relations between values and happiness are based on a purpose of human life and a search for meaning [30-33]. Happiness [34] that is used as a response to subjective well-being in psychology constitutes an area of positive psychology within the cognitive and emotional evaluation of people's lives [30]. Psychology was more focused on negative emotions like depression and anxiety in the past; whereas today, especially after the 1980s, the concept of "prosperity", "happiness" and "life satisfaction" has increased the relevance to the conditions, qualities and attitudes that define people's quality of life, and hence the concept of subjective well-being has begun to draw more attention [35]. Subjective well-being means people's evaluation of their lives; these may be judgments and assessments including life satisfaction, moods, and emotions. When people feel sad or amused, they feel that their lives are bad or go well. Therefore, subjective 
well-being, a scientific study of happiness and life satisfaction, is a heterogeneous category including various phenomena ranging from optimism to anger and job satisfaction, and involves a high level of pleasant emotions and moods and high life satisfaction, just as low levels of negative emotions and moods [36]. These positive life experiences that make people happy can only emerge through appropriate actions. Man's actions take place through the concepts of choice, preference, desire and passion. The choice is, therefore, to require a personal prediction of what kind of happiness is required prior to the decision-making process, and to consider what action is to be taken for the purpose of life, and to think about why others should not be done as well as acting accordingly. In this regard, these actions, which are to make people happy, are initially virtuous actions depending on the values, and an action occurs through desire, passion, choice or preference. Namely, when it comes to taking action, choice is a basic concept for the expected action. Because it is the preferences that will lead the person to happiness [37]. Moving these preferences on the basis of values or participating in activities that are sensitive to values will also encourage human happiness. Therefore, it seems possible to say that values constitute one of the important sources of human happiness, or that values can be effective in people's happiness, and education in this regard must be functional. When assessed in this respect, it is necessary to determine how effective the education provided to individuals is to have their own values and to be happy, and the university education which constitutes the last steps of education can be regarded as a criterion in this respect. Determining the value and happiness levels of university students as individuals trained at higher education level can be regarded as an important indicator in terms of questioning the functions of education. Because, one of the aims of education is to train happy individuals who have values. The educated human potential, which constitutes the most important source of societies and is expected to serve in vocationally important tasks in the next stage, is highly important in terms of community wellbeing and the future of society.In this respect, it is important to determine the value and happiness levels of university students. In the literature, some researches about the value levels and happiness of Turkish university students are found. Özkalp, Özdemir and Duyan, [38] studied the relationship between happiness and values in their studies. The happiness levels of students were researched in Solmaz [39], Şahin [40], Saygın and Arslan [41], Karahan, Dicle and Eplikoç[42] and Çevik and Yıldız[43], Researchers such as Özdemir and Koruklu [33], Solmaz[44], Coşkun and Yıldırım [45], Yllmaz [46] have tried to determine the value levels of university students in their studies. In this direction, in order to contribute to the literature, the study of the relationship between the level of values of university students and the level of happiness was considered as the main problem depending on this basic problem, the answers to the following questions have been searched.

\section{Materials and Methods}

Having examined the relation between university students' value orientations and their happiness levels, this research has employed relational screening model.

\subsection{Sample and Procedure}

The research sample holds a total of 412 third and fourth grade university students who study at the faculties of physical education and sports, education, science and letters, theology, business administration, engineering, forestry and agriculture at Kahramanmaraş Sütçü İmam University during the spring semester of 2016 and 2017 academic year. They were selected through convenience sampling method. 376 scale forms were found to be valid for analysis.

Table 1. Demographic Characteristics of the Participants

\begin{tabular}{|l|c|c|}
\hline Demographic Characteristics & N & $\%$ \\
\hline Gender & & \\
\hline Female & 242 & 64,4 \\
\hline Male & 134 & 35,6 \\
\hline Faculty/Vocational High School & & \\
\hline Physical Education and Sports & 39 & 10,4 \\
\hline Education & 83 & 22,1 \\
\hline Science-Letters & 58 & 15,4 \\
\hline Theology & 38 & 10,1 \\
\hline Business Administration & 42 & 11,2 \\
\hline Engineering & 25 & 6,6 \\
\hline Forestry & 28 & 7,4 \\
\hline Agriculture & 63 & 16,8 \\
\hline Class Level & 151 & 40,2 \\
\hline 3rd & & \\
\hline 4th & 225 & 59,8 \\
\hline
\end{tabular}

Among the participants, $64.4 \%$ were female and $35.6 \%$ were male. Considering faculties, $10.4 \%$ of them are physical education and sports, $22.1 \%$ are education, $15.4 \%$ are science and letters, $10.1 \%$ are theology, $11.2 \%$ are business administration, $6.6 \%$ are engineering, $7.4 \%$ are forestry and $16.8 \%$ are agriculture faculty students. $59.8 \%$ of the participants are in the 3rd class and $40.2 \%$ are in the 4th class level.

\subsection{Data Collection Tools}

This research has used "Personal Information Form" and "Values Scale" developed by the researcher taking into consideration the original tool developed by Calp [47]; the "Oxford Happiness Scale" developed by Dogan and 
Sapmaz [48].

\subsubsection{Personal Information Form}

Personal information form developed by the researcher in order to collect data about the independent variables includes 3 questions in total (gender, faculty or vocational high school, class level).

\section{2. 3. Values Scale}

The research has deployed the 'Values Scale' which was developed by the researcher through using the tool's original form developed by Calp [47] in order to determine students' value levels. The scale consists of 28 items. Aiming to identify students' values, the tool was prepared in 5 point likert-type varying between "Absolutely wrong" (1); " Absolutely true" (5). The total score of the scale is calculated provided that 5 of the items are reverse scored. The highest score is 140 while the lowest is 28 , and high scores indicate the increase in students' value levels. The Cronbach Alpha reliability coefficient of the scale was determined to be .87 , Kaiser-Meyer-Olkin (KMO) value was found to be .88 .

\subsubsection{Oxford Happiness Scale}

Oxford Happiness Scale, the Turkish adaptation of which was done by Doğan and Sapmaz [48], was developed by Hills and Argyle[49]. The scale comprises 29 items and a single factor. The Cronbach alpha internal consistency coefficient of the tool was found to be 0.91 . The tool was prepared in 6 point likert type varying across (1-Strongly disagree, 2- Moderately disagree, 3-Slightly disagree, 4-Slightly agree, 5-Moderately agree, 6-Strongly agree). 1st. 6. 10.13.14. 19. 23. 24. 27. 28. 29th items are scored in reverse. High scores indicate greater happiness.

Explanatory and confirmatory factor analysis methods were used to examine the construct validity of ÖMO. According to exploratory factor analysis results, a structure whose eigen value was 8.3 and which explained $29.84 \%$ of total variance was obtained. It was seen that the factor loads of the scale varied between 0.32 and 0.77 . The findings obtained as a result of confirmatory factor analysis indicated that the one-factor structure of the scale was retained in the sample comprising Turkish university students. Correlations of OMO with other measurement tools used in the scope of the study were examined for criterion related validity. There was a significant relationship between OMÖ and other measuring instruments evaluating happiness and optimism. The reliability of OMO has been investigated by means of compound reliability, internal consistency and test cleavage methods.In structural reliability analysis, Cronbach alpha internal consistency coefficient of OMÖ was found 0.91 and reliability coefficient obtained with test half-life method was found 0.86 and composite reliability of the scale was found 0.91 .

\subsection{Analysis of Data}

Data were analyzed through SPSS 15.0 packet statistical program. Arithmetic mean, frequency, standard deviation and percentage distributions were calculated in order to determine participants' socio-demographic characteristics, value and happiness levels. Pearson's moment product correlation analysis was used to identify the relationship between values and happiness levels, and Independent samples t-test to reveal the difference in values and happiness levels in terms of gender and class level. Besides, Kruskal-Wallis H-test was used to determine the difference in values and happiness levels depending on faculty. Significance level was taken as 0.05 .

\section{Findings}

Table 2. Arithmetic Mean and Standard Deviations of Students' Values and Happiness Levels

\begin{tabular}{|c|c|c|c|}
\hline Variables & $\mathrm{N}$ & $\begin{array}{c}\text { Arithmeti } \\
\text { c Mean }\end{array}$ & $\begin{array}{c}\text { Standard } \\
\text { Deviation }\end{array}$ \\
\hline 1.Values Level & 376 & 125,70 & 10,96 \\
\hline 2. Happiness Level & 376 & 116,80 & 19,16 \\
\hline
\end{tabular}

Table 2 depicts that the students have 125,70 arithmetic mean scores and 10,96 standard deviations of their value levels; while that of the arithmetic mean and standard deviation of their happiness level scores is 116,80 and 19,16 , respectively. Accordingly, it is likely to mention that students' value levels are high, while their happiness levels are above the average.

Table 3. Arithmetic Mean and Standard Deviation Values of Students' Value Levels by Faculty

\begin{tabular}{|c|c|c|c|}
\hline Faculties & $\mathrm{N}$ & $\begin{array}{c}\text { Arithmetic } \\
\text { Mean }\end{array}$ & $\begin{array}{c}\text { Standard } \\
\text { Deviation }\end{array}$ \\
\hline Theology & 38 & 130,18 & 9,83 \\
\hline Education & 83 & 128,93 & 9,74 \\
\hline Agriculture & 63 & 126,98 & 10,46 \\
\hline $\begin{array}{c}\text { Physical education } \\
\text { and sports }\end{array}$ & 39 & 126,97 & 10,14 \\
\hline $\begin{array}{c}\text { Science-Letters } \\
\text { Business }\end{array}$ & 58 & 126,53 & 9,45 \\
\hline Administration & 42 & 120,33 & 10,84 \\
\hline Engineering & 25 & 119,08 & 12,72 \\
\hline Forestry & 28 & 117,67 & 10,91 \\
\hline
\end{tabular}

Upon analyzing students' value level scores by faculty, theology faculty students possess the highest mean, which is respectively followed by those from the faculties of education, agriculture, physical education and sports, science and letters, business administration, engineering and forestry. 
Table 4. Arithmetic Mean and Standard Deviation Values of Students' Happiness Levels by Faculty

\begin{tabular}{|c|c|c|c|}
\hline Faculties & $\mathrm{N}$ & Arithmetic Mean & $\begin{array}{c}\text { Standard } \\
\text { Deviation }\end{array}$ \\
\hline Theology & 38 & 124,44 & 16,81 \\
\hline Forestry & 28 & 119,85 & 14,61 \\
\hline Agriculture & 63 & 119,01 & 20,77 \\
\hline $\begin{array}{c}\text { Physical } \\
\text { education and } \\
\text { sports }\end{array}$ & 39 & 118,82 & 17,09 \\
\hline Education & 83 & 118,53 & 20,33 \\
\hline Science-Letters & 58 & 113,56 & 20,12 \\
\hline $\begin{array}{c}\text { Business } \\
\text { Administration }\end{array}$ & 42 & 109,64 & 16,90 \\
\hline Engineering & 25 & 106,88 & 16,43 \\
\hline
\end{tabular}

Considering students' happiness level scores by faculty in Table 4, theology faculty students have the highest mean. This is followed by the scores of forestry, agriculture, physical education and sports, education, science and letters, business administration and engineering faculty students.

Table 5. Pearson Moments Multiplication Correlation Results of Students' Values and Happiness Levels

\begin{tabular}{|c|c|c|}
\hline Variables & Values & Happiness \\
\hline Values & - & $.356^{* *}$ \\
Happiness & & - \\
\hline
\end{tabular}

$\mathrm{N}=376$

$* * \mathrm{p}<.01$

Table 5 suggests a significant, medium relationship between students' values and happiness levels at the.01 level $\mathrm{r}=0,35, \mathrm{p}<.01)$.

Table 6. Independent Group t-test Results of Students' Values and Happiness Levels in terms of Gender

\begin{tabular}{|c|c|c|c|c|c|c|c|}
\hline & Gender & $\mathrm{N}$ & Arithmetic Mean & Standard Deviation & $\mathrm{df}$ & $\mathrm{t}$ & $\mathrm{p}$ \\
\hline \multirow{2}{*}{ Value Scores } & Female & 242 & 127,30 & 9,74 & \multirow{2}{*}{224,93} & \multirow{2}{*}{3,60} & \multirow{2}{*}{, 000} \\
\hline & Male & 134 & 122,82 & 12,40 & & & \\
\hline \multirow{2}{*}{ Happiness Scores } & Female & 242 & 118,76 & 19,21 & \multirow{2}{*}{374} & \multirow{2}{*}{2,69} & \multirow{2}{*}{,007 } \\
\hline & Male & 134 & 113,26 & 18,62 & & & \\
\hline
\end{tabular}

As seen in Table 6, a significant difference has been noted between students' values scores depending upon gender in favor of female students $(\mathrm{t}=3,60 ; \mathrm{p}<.001)$. A similar result has been identified in terms of students' happiness scores $(\mathrm{t}=$ $2,69 ; \mathrm{p}<.01)$.

Table 7. Independent Group t-test Results of Students' Values and Happiness Levels in terms of Class Level

\begin{tabular}{|c|c|c|c|c|c|c|c|}
\hline & Class & $\mathrm{N}$ & Arithmetic Mean & Standard Deviation & df & $\mathrm{t}$ & $\mathrm{p}$ \\
\hline \multirow{2}{*}{ Value Scores } & $3 \mathrm{rd}$ & 225 & 124,18 & 11,34 & \multirow{2}{*}{347,80} & \multirow{2}{*}{$-3,41$} & \multirow{2}{*}{, 001} \\
\hline & 4th & 151 & 127,97 & 9,97 & & & \\
\hline \multirow{2}{*}{ Happiness Scores } & $3 \mathrm{rd}$ & 225 & 115,39 & 18,69 & \multirow{2}{*}{374} & \multirow{2}{*}{$-1,74$} & \multirow{2}{*}{, 082} \\
\hline & 4 th & 151 & 118,90 & 19,72 & & & \\
\hline
\end{tabular}

Table 7 reveals a significant difference for the value levels of the students in favor of those in the 4th class $(\mathrm{t}=-3,41$; $\mathrm{p}<.01$. On the other, no significant difference has been observed between students' happiness levels and their class levels $(\mathrm{t}=-1,74 ; \mathrm{p}>.01)$.

Table 8. Kruskal Wallis-H Test Results of Students' Values Levels in terms of Faculty

\begin{tabular}{|c|c|c|c|c|c|c|c|}
\hline Variables & Faculties & $\mathrm{N}$ & S.O & $\mathrm{df}$ & $X^{2}$ & $\mathrm{p}$ & Significant difference \\
\hline \multirow[t]{8}{*}{ Values } & A-Physical education and sports & 39 & 200,05 & 7 & 53,08 & .000 & \multirow{8}{*}{$\begin{array}{c}\mathrm{A}>\mathrm{E}, \mathrm{A}>\mathrm{F}, \mathrm{A}>\mathrm{G} \\
\mathrm{B}>\mathrm{C}, \mathrm{B}>\mathrm{E}, \mathrm{B}>\mathrm{F}, \mathrm{B}>\mathrm{G} \\
\mathrm{C}>\mathrm{E}, \mathrm{C}-\mathrm{F}, \mathrm{C}>\mathrm{G} \\
\mathrm{A}, \mathrm{D}>\mathrm{B}, \mathrm{D}>\mathrm{C}, \mathrm{D}>\mathrm{E}, \mathrm{D}>\mathrm{F}, \mathrm{D}>\mathrm{G} \\
\mathrm{H}>\mathrm{E}, \mathrm{H}>\mathrm{F}, \mathrm{H}>\mathrm{G}\end{array}$} \\
\hline & B- Education & 83 & 224,02 & & & & \\
\hline & C-Science-Letters & 58 & 189,64 & & & & \\
\hline & D- Theology & 38 & 240,16 & & & & \\
\hline & E- Business Administration & 42 & 132,36 & & & & \\
\hline & F- Engineering & 25 & 126,98 & & & & \\
\hline & G-Forestry & 28 & 108,36 & & & & \\
\hline & H- Agriculture & 63 & 199,80 & & & & \\
\hline
\end{tabular}

'Kruskal Wallis-H' test shows that there exists a statistically significant difference between students' rank order depending on their faculties $\left(\mathrm{x}^{2}=53,865 ; \mathrm{p}<.05\right)$. 'Mann Whitney-U' test reveals that students from the physical education and sports department have higher levels of happiness compared to those from the faculties of business administration, engineering and forestry; education faculty students in comparison to science and letters, business administration, engineering and forestry students; theology students compared to science and letters, business administration, engineering and forestry students; agriculture faculty students compared to business administration, engineering and forestry students. 
Table 9. Kruskal Wallis-H Test Results of Students' Happiness Levels in terms of Faculty

\begin{tabular}{|c|c|c|c|c|c|c|c|}
\hline Variables & Faculties & $\mathrm{N}$ & S.O & df & $\mathrm{X}^{2}$ & $\mathrm{p}$ & Significant difference \\
\hline \multirow[t]{8}{*}{ Happiness } & $\begin{array}{l}\text { A-Physical education and } \\
\text { sports }\end{array}$ & 39 & 202,01 & 7 & 25,41 & .001 & \multirow{8}{*}{$\begin{array}{c}\mathrm{A}>\mathrm{E}, \mathrm{A}>\mathrm{F} \\
\mathrm{B}>\mathrm{E}, \mathrm{B}>\mathrm{F} \\
\mathrm{D}>\mathrm{C}, \mathrm{D}>\mathrm{E}, \mathrm{D}>\mathrm{F} \\
\mathrm{G}>\mathrm{E}, \mathrm{G}>\mathrm{F} \\
\mathrm{H}>\mathrm{E}, \mathrm{H}-\mathrm{F}\end{array}$} \\
\hline & B- Education & 83 & 199,87 & & & & \\
\hline & C-Science-Letters & 58 & 173,97 & & & & \\
\hline & D- Theology & 38 & 233,08 & & & & \\
\hline & E- Business Administration & 42 & 141,87 & & & & \\
\hline & F- Engineering & 25 & 129,58 & & & & \\
\hline & G-Forestry & 28 & 209,14 & & & & \\
\hline & H- Agriculture & 63 & 196,94 & & & & \\
\hline
\end{tabular}

'Kruskal Wallis-H' test suggests that there is a statistically significant difference between students' rank order depending on their faculties $\left(\mathrm{x}^{2}=25,863 ; \mathrm{p}<.05\right)$. 'Mann Whitney-U' test conducted to determine the source of the difference puts forward that students from the physical education and sports department have higher levels of happiness compared to business administration and engineering students; education faculty students in comparison to business administration and engineering students; theology students compared to science and letters, business administration and engineering students; forestry students in comparison to business administration and engineering students; agriculture faculty students compared to business administration and engineering students.

\section{Results, Discussion and Recommendations}

The values expressing the rules that set ground for the emotion, thoughts and behaviors of a person who is a social entity provide life satisfaction to make the person happier by contributing to the process of socialization and meaning as well as defining the existential purpose and positive relations with common values.

Considering that values will be a significant factor in human happiness, the research findings have revealed that university students' values are moderately high and their happiness levels are above average; moreover a positive and medium level of relationship has been identified between the values and happiness levels of the students. So to speak, as the level of value increases, happiness also increases. Similar results have been found in Özkalp, Özdemir and Duyan's [38] and Özdemir and Koruklu [33] studies.

When we examine the researches about the values and happiness levels of Turkish university students, we also see that the values of the university students are high in Özdemir and Koruklu [33], Solmaz [44], Y1lmaz [46] Coşkun and Yıldırım [45]. Again, in some studies in which the happiness levels of students are examined, positive emotional variables are positively correlated with life satisfaction, spirituality and optimism, there was a negative relationship between trait anxiety, state anxiety and negative emotions [50]. It is seen that the happiness levels of the students are above the average level of happiness in Solmaz [39], Şahin [40], Saygın and Arslan [41], Karahan, Dicle and Eplikoç [42] and Çevik and Yıldız's [43] in their study, students appear to be of above average levels of happiness.

Given the values and happiness levels of the students in terms of gender, female students have higher values and happiness levels in comparison to male students. Having analyzed the values in literature, several studies have concluded that female university students have higher levels of value [44,51], while high value orientations of male and female university students vary across the sample group [16,33,52-55]. This research has found that female students have higher value levels, which may be due to the socio-cultural and demographic characteristics of the sample.

When the results have been evaluated in terms of happiness, happiness levels of female students was found to be higher. This finding is supported by various researches [56-58]. However, some researches have also suggested that happiness is free from any significant difference in terms of gender [59].

When it comes to students' value levels by class levels, students in the 4th grade possess higher value levels than those in the 3rd grade; whereas those in the 4th grade have higher happiness levels than in the 3rd grade despite no significant difference. In terms of values, this can be regarded as an acquisition after one year of over-education; on the other, the happiness level of the 4 th grade students is higher since they may be feel relaxed due to graduation excitement.

When the value levels of the students are ranked by faculty, the faculty of theology has the highest level, while the lowest level goes to forestry faculty students. This may have been the effect of the content of the education as religious knowledge is, in particular, one of the important sources in the development of values. Students who are equipped with such education are expected to have higher 
awareness and sensitivity of values. In addition, education faculty students are ranked as the second, which may be considered as an expected result since prospective teachers are well equipped with values to transfer them to the new generation.

As for the students' happiness levels by faculty, those from the faculty of theology have the highest happiness level. This may be explained by the relationship between values and happiness. As the orientation to values increases, happiness will also increase. What is more, the course content of the theology faculty and the spiritual orientations of the students may also be considered to be influential in the increase in the students' happiness levels. Yilmaz's [46] research on university students found that religious orientations of participants had the same and meaningful relationships between individual value preferences, discipline and responsibility values, trust and forgiveness values, and respect and truthfulness values.Similar findings were found in Göçen's [60] study conducted with adults and a positive relationship was found between happiness and religious orientation. The highest level of happiness in theology faculty students is followed by forestry, agriculture and physical education and sports faculties. This finding suggests that being engaged in nature and sports is also an important factor in happiness. Undoubtfully, it would be helpful to explain these results and interpretations with researches to be carried out with other samples with different demographic characteristics.

\section{Acknowledgement}

Earlier version of this research was presented at the 4th International Conference on Social Sciences and Education Research, a conference held at Ankara, Turkey, September 2017.

\section{REFERENCES}

[1] B. Möngü. Modern Dünyada Mutluluk: John Stuart Mill'in Faydac1 Etiği. Atatürk Üniversitesi Sosyal Bilimler Enstitüsü Dergisi, Vol. 19, No.1, 23-30, 2015.

[2] G. Şaylan. Postmodernizm, İmge Kitabevi, Ankara, 2009.

[3] Ö. Özaydın. Modernliğin Akılcılık ve Evrenselcilık İddialarının Felsefe Kökeni / The Philosophical Foundation of Modernity's Claims of Rationalism and Universalism, Doğuş Üniversitesi Dergisi, Vol.12 No.1, 74-83, 2011.

[4] G. A. Yaşar. Ortaçağdan Günümüze "Modernite":Doğuşu ve Doğas,. Adıyaman Üniversitesi Sosyal Bilimler Enstitüsü Dergisi, Vol. 4, No.7, 10-26, 2011.

[5] B. Akarsu. Değișen Dünya, Değișen Değerler, İnkılap Kiatabevi, İstanbul, 2006.
[6] H. İ. Bahar. Sosyoloji. Uluslar Arası Stratejik Araştırmalar Kurumu Yayıları:19, Ankara, 2008.

[7] M. Yüksel. Modernleşme Bağlamında Hukuk ve Etik İlișkisine Sosyolojik Bir Bakıș. Ankara Üniversitesi SBF Dergisi. Vol. 57, No.1, 177-195, 2002.

[8] M. E. Şimşek. Moderniteden Postmoderniteye Uzanan Bir Köprü: Zygmunt Bauman, Basılmamış Yüksek Lisans tezi, Atatürk Üniversitesi Sosyal Bilimler Enstitüsü Felsefe Anabilim Dalı, Erzurum, 2014

[9] A. Bahadır. Modernitenin Yıkıcı Etkileri Karșısında Savunmasız İnsan, Selçuk Üniversitesi İlahiyat Fakültesi Dergisi, Vol.13, 129-142, 2002.

[10] N. Tarhan. İnanç Psikolojis,. Ruh, Beyin ve Akıl Üçgeninde İnsanoğlu, Timaş yayınları, İstanbul, 2009

[11] D. Bhardwaj, H. K. Tyagi, D. Ameta. A Study on the Role of School Curriculum and Teachers in Inculcation of Values among Elementary School Students, Online available from http://iiste.org/Journals/index.php/JEP.

[12] A. Akpınar. Yağmur Dergisindeki Hikayelerde Değerler Eğitimi: 2004-2014, Yayımlanmamış Yüksek Lisans Tezi. Çanakkale Onsekizmart Üniversitesi, Sosyal Bilimler Enstitüsü. Çanakkale, 2015.

[13] Ö. Köknel.. Çatışan Değerlerimiz, Altın Kitaplar Yayınevi, İstanbul, 2007.

[14] N. Toku. 'Değerlerin Dilemması: Subjektiflik ve Objektiflik', Bilgi ve Değer Sempozyumu Bildirileri (Edit: Şahabettin Yalçın), Vadi Yayınları, 1. Baskı, Ankara, 2002.

[15] H. Selsam. Etik (Yeni Değerler ve Özgürlük) (Çev:Yüksel Demirekler), Yaba Yayınları:58, 1. Basım, Ankara, 1995.

[16] H. Bacanl1. Üniversite Öğrencilerinin Değer Tercihleri, Kuram ve Uygulamada Eğitim Yönetimi, Vol.5, No.4, 597-610, 1999.

[17] Türkçe Bilim Terimleri Sözlüğü. Türkiye Bilimler Akademisi (TÜBA), Ankara, 2011.

[18] I. Bagga \& S. Saini. A Comparative Analysis of The Value System of Adolescents and Their Parents. Indian Journal of Health \& Wellbeing, Vol. 8 No.4, 268-271, 2017. Access number: 123333763.

[19] M. Z. Aydın. Okulda Değerler Eğitimi, Eğitime Bakış, Vol.6, No.18, 16-19, 2010.

[20] H. Z. Ülken. Bilgi ve Değer, Aytemiz Kitabevi, Kürsü yayınları No:8, Ankara, 1967

[21] E. Güngör. Değerler Psikolojisi Üzerinde Araştırmalar, Ötüken Neşriyat, İstanbul, 2010.

[22] E. Kolaç and S. Ç Zenci. Açık Öğretim Ortaokulu Türkçe Ders Kitaplarındaki Metinlerde Yer Alan Değerler, Journal of Academic Studies. may-tem2015, Vol. 17, No.65, 145-171, 2015.

[23] E.Özgür. Yaşa Göre Değer Farklılıkları ve Siyasi Kuşak Aidiyeti. Sosyoloji Dergisi, Vol. 26. No.1, 45-76, 2013.

[24] C.İ Demirhan. Values Education and Some Suggestions to Teachers / Değerler Eğitimi ve Öğretmenlere Bazı Öneriler, Hacettepe Üniversitesi Eğitim Fakültesi Dergisi, Vol. 40, 245-255, 2011. 
[25] S.Turan and D. Aktan.. Okul Hayatında Var Olan ve Olması Düşünülen Sosyal Değerler, Türk Eğitim Bilimleri Dergisi, Vol. 6, No.2, 227-259, 2008.

[26] A. H. Kalkandelen. Pendnameler Ișığında İnsani Değerler. Atatürk Üniversitesi İlahiyat Fakültesi Dergisi, Vol.43, 286-305, 2015.

[27] A. Güneş. Manevi-İnsani Değerler Eğilim Ölçeği (MIDÖ): Geçerlik ve Güvenirlik Çalışması// Tendency Scale Of Spıritual-Humanıstıc Values: A Study About The Reliability and Validity, Journal of International Social Research, Vol. 8 No. 41, 1354-1360, 2015.

[28] H. Gökhan. 100 Terimde Bütün Felsefe. Kafekültür Yayıncılık, İstanbul, 2013.

[29] Ö. Köknel. Kaygıdan Mutluluğa Kişilik. Altın Kitaplar Yayınevi, İstanbul, 1995.

[30] E. Diener. "Subjective Well-Being: The Science of Happiness and Proposal for National Index", American Psychologist, Vol.1, 34-43, 2000.

[31] O. Hellevik. Economy, Values and Happiness in Norway, Journal of Happiness Studies Vol.4, 243-283, 2003

[32] L. Luo \& J. B Shih. Sources of Happiness: A Qualitative Approach, The Journal of Social Psychology, Vol.137, N.2, 181-187, 1997. DOI: 10.1080/00224549709595429

[33] Y. Özdemir and N. Koruklu. Investigating Relatinship Between Values and Happiness Among University Students. YYÜ, Eğitim Fakültesi Dergisi, Vol. 8, No.1, 190-210, 2011.

[34] T. Doğan and A. Eryılmaz. Akademisyenlerde İşle İlgili Temel İhtiyaç Doyumu ve Öznel İyi Oluş / Work-Related Basic Need Satisfaction and Subjective Well-Being Among Academicians, Ege Akademik Bakıș Dergisi, V. 12, No.3, 383-389, 2012.

[35] D. G.Myers and E. Diener. Who Is Happy? Psychological Science, Vol.6, No.1, 10-19, 1995.

[36] E. Diener \& M. Y. Chan. Happy People Live Longer: Subjective Well-Being Contributes to Health and Longevityaph,. Applied Psychology: Health and Well-Being, Vol. 3 No.1, 1-43, 2011. doi:10.1111/j.1758-0854.2010.01045.x

[37] T. Çötok. Aristoteles'te Tercih - Mutluluk İlişkisi ve Kahneman'c1 bir Değerlendirme / The Relationship Between Deliberate-Choice and Happiness in Aristotle: A Kahnemanian Perspective, The Journal of Happiness \& Well-Being, Vol.5, No.1, 113-121, 2017.

[38] E. Özkalp, A. A. Özdemir and E. C. Duyan. Değer Tipleri ve Öznel İyi Oluş Arasındaki İlișkide Örgütsel Vatandaşlık Davranışının Aracılık Rolü, "İŞ, GÜÇ" Endüstri İlișkileri ve İnsan Kaynakları Dergisi, Vol. 18, No.1, 1-22, 2016.

[39] D. Y. Solmaz. Öğretmen Adaylarının Öznel İyi Oluş Düzeyleri: Anadolu Üniversitesi Beden Eğitimi ve Spor Öğretmenliği Bölümünde Bir Araştırma/ The Subjective well-Being Levels of Teacher Candidates: A Research Department of Physical Education And Sports teaching at Anadolu University, Vol: 7 Issue: 35, 651-657, 2014

[40] G. N. Şahin. Üniversite Öğrencilerinin Kendini Açma, Öznel İyi Oluş ve Algıladıkları Sosyal destek Düzeylerinin karşılaștırılması, Dokuz Eylül Üniversitesi Eğitim Bilimleri Enstitüsü, Basılmamış Yüksek Lisans Tezi, 2011.

[41] Y. Saygın and C. Arslan, Üniversite Öğrencilerinin Sosyal Destek, Benlik Saygısı ve Öznel İyi Oluş Düzeylerinin İncelenmesi/An Investigation Social Support,Self Esteem and Subjective Wel-Being Level of College Students, Selçuk Üniversitesi Ahmet Keleşoğlu Eğitim Fakültesi Dergisi, No.28, 207-222, 2009.

[42] T. F. Karahan, A. N. Dicle and H. Eplikoç. Üniversite Öğrencilerinin Stresle Başaçıkma Tarzlarının Sosyal Beceri Düzeylerine ve Mutluluk Algılarına Göre İncelenmesi. Ankara Üniversitesi, Eğitim Bilimleri Fakültesi Dergisi, 40 (2), 41-61, 2007

[43] G. B. Çevik , M. A. Yıldız. Pedagojik Formasyon Öğrencilerinde Umutsuzluk ile Mutluluk Arasındaki İlişkide Benlik Saygısının Aracılık Rolü, Dicle Üniversitesi, Eğitim Fakültesi Dergisi, Vol. 27, 96-107, 2016.

[44] D. Y. Solmaz. Öğretmen Adaylarının insani Değer Düzeyleri: Anadolu üniversitesi Beden eğitimi ve Spor Öğretmenliği Bölümünde Bir Araşrtırma / The Human Value Levels of Teacher Candiates: A Research department of Physical education and Sports Teaching at Anadolu University. Uluslararası Sosyal Araștırmalar Dergisi / The Journal of International Social Research. Vol. 8, No. 41, 1069-1076, 2015.

[45] Y. Coşkun and A. Yıldırım. Üniversite Öğrencilerinin Değer Düzeylerinin Bazı Değişkenler Açısından İncelenmesi, Yüzüncü Y1l Üniversitesi, Eğitim Fakültesi Dergisi, Vol.6, No.1, 311-328, 2009.

[46] K. Yılmaz. Üniversite Öğrencilerinin Dini Yönelimleri İle Bireysel Değerleri Arasındaki İlişki, Balıkesir Üniversitesi Sosyal Bilimler Enstitüsü Dergisi, Vol. 16, No. 29, 129-146, 2013

[47] O. Calp. Lise Son Sınıf Öğrencilerinin Sosyal Değerlere Bakışlarının İncelenmesi (Hatay Merkez İlçe Örneği), Yayımlanmamış yüksek lisans tezi, Gazi Üniversitesi, Eğitim Bilimleri Enstitüs,. Ankara, 2006.

[48] T. Doğan and F. Sapmaz,. Oxford Mutluluk Ölçeği Türkçe Formunun Psikometrik Özelliklerinin Üniversite Öğrencilerinde İncelenmesi. Düşünen Adam Psikiyatri ve Nörolojik Bilimler Dergisi Vol. 25, 297-304, 2012. DOI: 10.5350/DAJPN2012250401

[49] P. Hills \& M. Argyle. The Oxford Happiness Guestionnaire: A Compact Scale for The Measurement of Psychological Well-Being. Personality and Individual Differences 33, 1073-1082, 2002.

[50] A. Öztürk and R. S. Cetinkaya, Eğitim Fakültesi Öğrencilerinin Öznel İyi Oluş Düzeyleri ile Tinsellik, İyimserlik, Kaygı ve Olumsuz Duygu Düzeyleri Arasındaki İlişki. Marmara Üniversitesi Atatürk Eğitim Fakültesi Eğitim Bilimleri Dergisi / Journal of Educational Sciences. Vol. 42, 335-356, , 2015. DOI: 10.15285/ebd.98899.

[51] U. Keskin, H. İ. Sağlam. Sınıf Öğretmeni Adaylarının İnsani Değerlere Sahip olma Düzeylerinin Çeşitli Değişkenler Açısından İncelenmesi, Sakarya University Journal of Education, Vol.4, No.1, 81-101, 2014.

[52] N. Akkaya. Eğitim Fakültesi Öğrencilerinin Değer Tercihleri (DEU, Buca Egt. Fak. Örneği), Türkiye Sosyal 
Araştırmalar Dergisi, Vol.17, No. 2, 69-82, 2013.

[53] S. S. Bulut.. Gazi Eğitim Fakültesi Öğrencilerinin Değer Yönelimleri.Uluslararası Türkçe Edebiyat Kültür Eğitim Dergisi Vol. 1, No.3, 216-238, TÜRKIYYE International Journal of Turkish Literature Culture Education Vol. 1, No.3, 216-238, 2012.

[54] B. Dilmaç, H.Bozgeyikli, Y. Çıkılı. Öğretmen Adaylarının Değer Algılarının Farklı Değişkenler Açısından İncelenmesi. Değerler Eğitimi Dergisi, Vol. 6, No. 16, 69-91, 2008.

[55] M. Bilgin. Üniversite Öğrencilerinin Değerlerinin ve Fonksiyonel Olmayan Tutumlarının Bazı Değişkenler Açısından İrdelenmesi (Investigating University Students Values and Their Dysfunctional Attitudes in Relation to Some Variables), Çukurova Üniversitesi Sosyal Bilimler Enstitüsü Dergisi, Vol. 8, No.8, 33-53, 2001.

[56] R. Gündoğdu and Y. Yavuzer. Eğitim Fakültesi Öğrencilerinin Öznel İyi Oluş ve Psikolojik İhtiyaçlarının Demografik Değişkenlere Göre İncelenmesi / Examining Subjective Well-Being and Psychological Needs of Students at the Educational Faculty According to Demographic
Variables, Mehmet Akif Ersoy Üniversitesi Eğitim Fakültesi Dergisi, Vol.12, No. 23, 115 - 131, 2012.

[57] B. Dilmaç and H. Bozgeyikli. Öğretmen Adaylarının öznel İyi olma ve Karar Verme Stillerinin İncelenmesi /A Research on Subjective Well-Being and Decision Making of Teacher Candidates, Erzincan Eğitim Fakültesi Dergisi, Vol. 11, No.1,171-187, 2009.

[58] B. Kuyumcu. Türk ve İngiliz Üniversite Öğrencilerinin Psikolojik İyi Oluş Duygusal Farkındalık ve Duygularını İfade Etmelerinin Ülke ve Cinsiyet Değişkenlerine Göre İncelenmesi / Investigation of Psychological Well-Being Emotional Awareness and Expression of Emotion of Turkish and English University Students with Respect to Country and Gender, Erzincan Üniversitesi Eğitim Fakültesi Dergisi, Vol.14, No.2, 1-24, 2012.

[59] Z. C. Çankaya. Öğretmen Adaylarında temel Psikolojik İhtiyaçların Doyumu ve İyi Olma, Türk Eğitim Bilimleri Dergisi, Vol.7, No.3, 691-711, 2009.

[60] G. Göcen. Pozitif Psikoloji Düzleminde Psikolojik İyi Olma ve Dini Yönelim İlişkisi: Yetişkinler Üzerine Bir Araștırma, Toplum Bilimleri Dergisi, Vol.7, No.13, 97-130, 2013. 